\title{
Expansão da Unidade de Refinação da Petrogal em Sines
}

\author{
B ILL COLEMAN, GEORGE BUKOTA*
}

A Petróleos de Portugal - Petrogal, S.A., expandiu recentemente a sua unidade de refinaria em Sines através da criação de um novo complexo industrial estimado em 13 milhões de contos. O objectivo principal com esta expansão foi a de aumentar a capacidade de produção por parte da Petrogal de gasolina de alto rendimento e fuel por cada barril de "crude" refinado. Cerca de $43 \%$ da produção total serão destinados a gasolina sem chumbo atendendo ao aumento da procura deste produto em Portugal e no resto da Europa. O novo complexo apresenta como elemento importante uma unidade de alquilação por ácido fluorídrico (sob licença da Phillips Petroleum Company), que permite um enriquecimento no número de octanas de gasolina sem chumbo através da hidrogenação e isomerização de hidrocarbonetos leves demasiado voláteis para serem usados directamente na gasolina.

A unidade, com cerca de 60000 metros quadrados, iniciou a sua produção em Julho de 1994.

Petróleos de Portugal, S.A. (Petrogal) is wringing more high-value gasoline and jet fuel from each barrel of crude feedstock with a $\$ 650$ million (U.S.) expansion of its refinery in SINES, Portugal.

Petrogal increased its production of gasoline and jet fuel by 25.5 million barrels per year. This is a jump of 45 percent over production before the refinery expansion. From the new expansion, 11 million barrels, or 43 percent of the total, will be devoted to unleaded gasoline production to meet growing demand in Portugal and the rest of Europa. At the same time, the heavier, less valuable products such as residual fuel and asphalt - once accounting for 52 percent - now account for 34 percent of the refinery product mix.

The key to gain higher processing efficiencies for unleaded gasoline production is the new 5,400- square meter $(58,000$ square foot), \$85 million Gasoline Complex.

Major units erected for the refinery expansion included a 35,000 BPSD (barrel-per-stream-day) Fluidized Catalytic Cracker, a 26,000 BPSD Viscosity Breaker, a 45,000 BPSD Vacuum Distillation Unit, two extractive mercaptan columns, an amylene treater, a sulfur recovery system and an 8,000 BPSD alkylation processing complex.

The refinery expansion began February 1992 and was completed in June 1994.

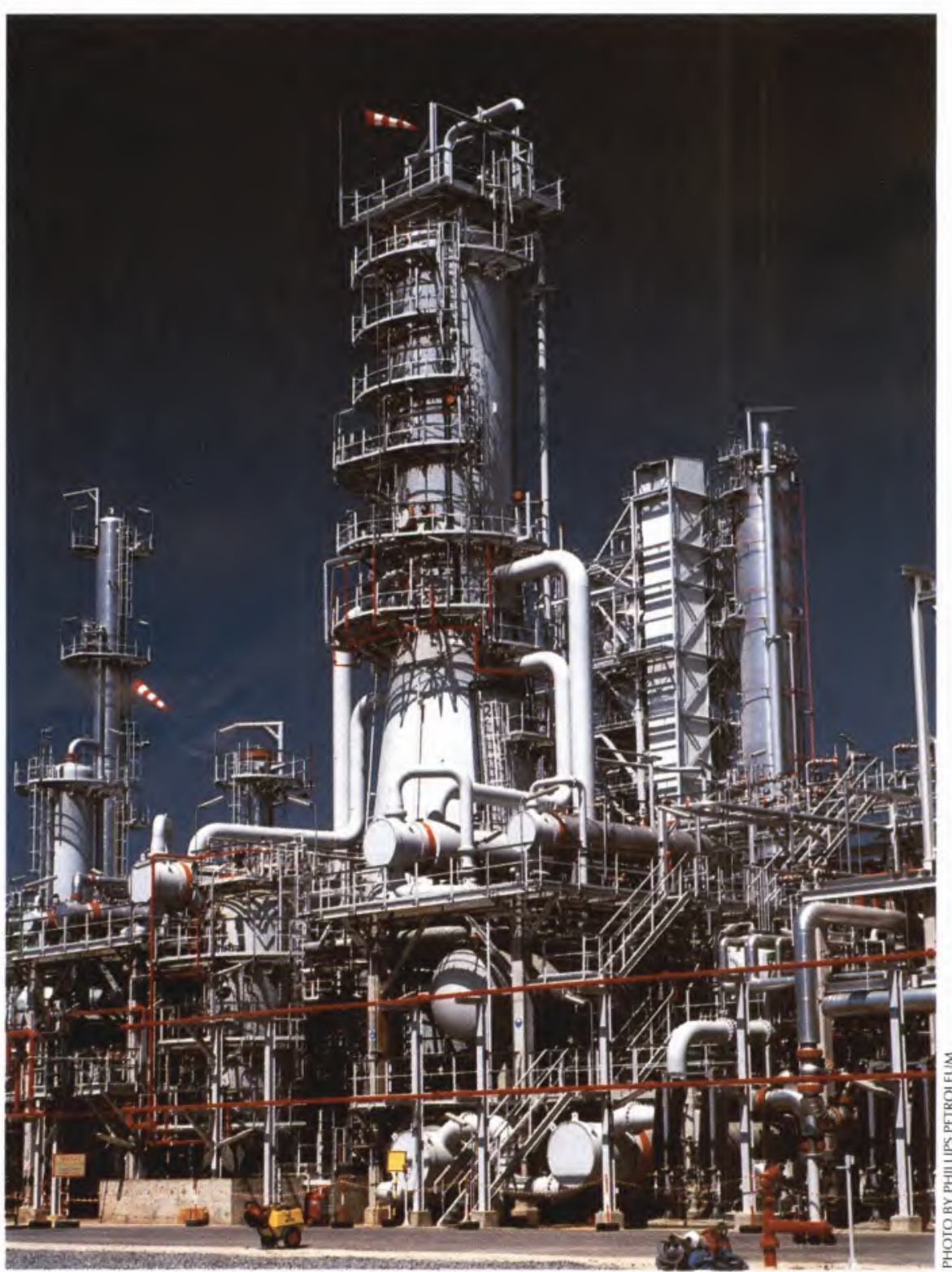

\section{PHILLIPS PETROLEUM PROCESSES SELECTED}

"Our plan was to build a worldscale refinery for domestic and export supplies of unleaded gasoline," said Carlos Pombo Rodrigues, director general of the Sines refinery expansion Project. "One key element in that plan was to select the most cost-effective advanced technology to produce $8,000 \mathrm{BPSD}$ of blending agents for environmental fuel. These trogal's new Gasoline Complex. processing units would become Pe- 


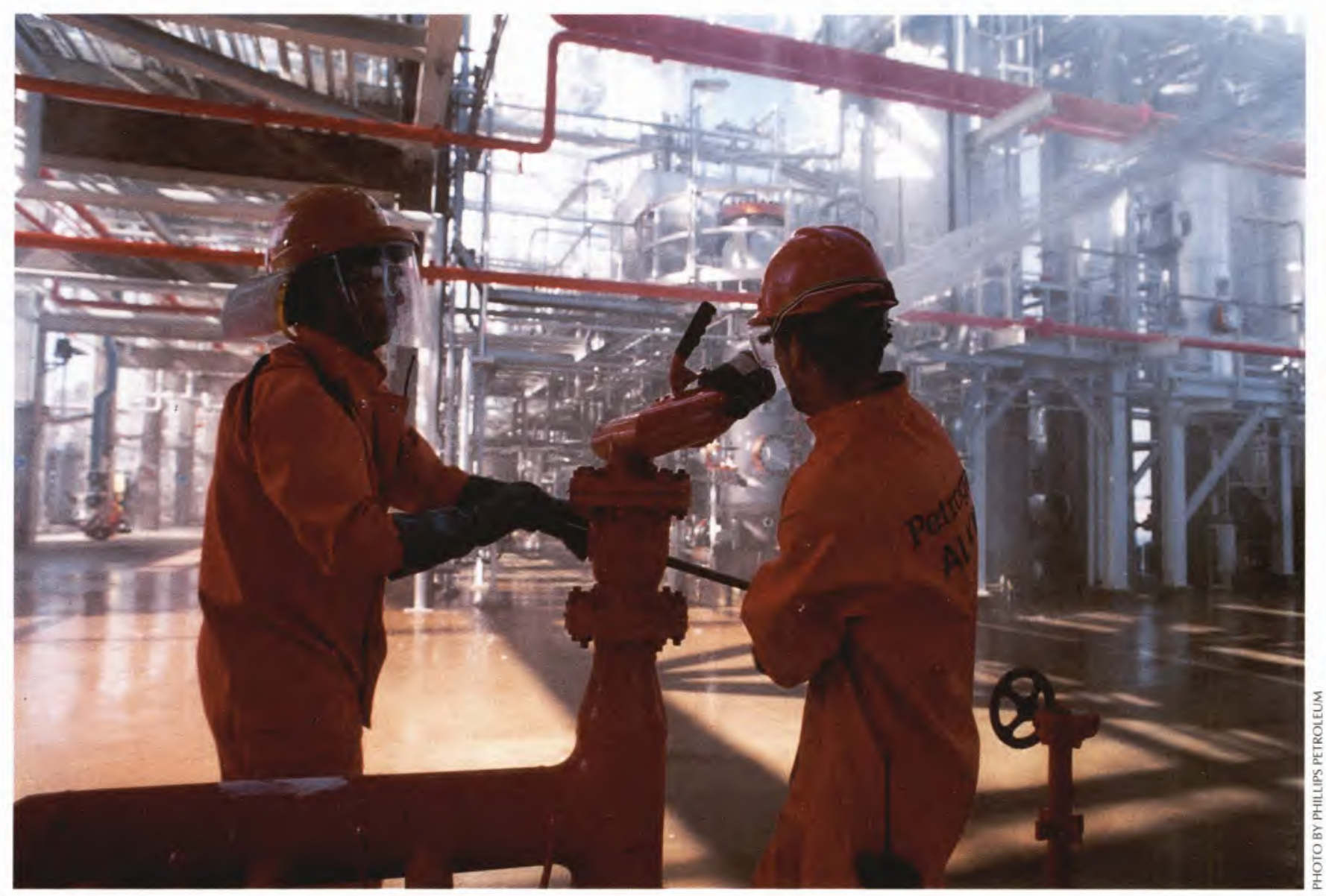

“We selected Phillips Petroleum Company's licensed technology for its HF (hvdrofluoric acid) Alkylation and Hydrisom units. We use the blending agent (alkylate) produced with these units to boost gasoline octane without the need for adding lead," he said.

\section{Safe Alkylation: A key to profits}

Alkylation uses hydrofluoric or sulfuric acid as a catalyst to combine light hydrocarbons too volatile to be used in gasoline. The larger molecules formed in this reaction are used as a high-octane blending agent to boost octane in unleaded gasolines.

Using alkylate to increase unleaded motor fuel octane also reduces olefins, aromatics and other substances which are restricted in today's environmental fuels.

One major factor in the decision was the greater consumption of acid catalyst in the alternative sulfuric acid process, which would have required Petrogal to regenerate 100 tons of sulfuric acid per day.

"Since we had no on-site sulfuric acid regeneration capabilities, we would have had to ship sulfuric acid from Ghent, Belgium, to our port facilities here, then transport five 20- ton trucks to the refinery each day," Pombo Rodrigues said. "This would require our company to build new harbor facilities, new roads and purchase a fleet of trucks just for sulfuric acid transport.

"Beyond this enormous commercial penalty, we would also be faced with the possibility of safety risks to the community by moving that much acid daily," he added.

The Phillips HF Alkylation unit design uses gravity to move HF through the system, eliminating maintenance-intensive pumps and the high operating pressures required by other alkylation technologies.

The Phillips HF Alkylation unit design also eliminates reactor stirrers, and eliminates or reduces the need for circulating pumps, shaft seals and gasketed connections in the reactor circuit. The only pump moving concentrated HF in the Phillips design is the one feeding the acid regenerator circuit.

The new Gasoline Complex includes the Phillips Petroleum designed Hydrisom unit for selective diolefin hydrogenation, a defluorinator to remove fluorides from butane and propane, an HF stripper, a depropanizer, the vertical HF reactor/settler, fluidized catalytic cracking unit (FCCU) and feedstock heater using refinery fuel gas and acid soluble oil (ASO) for fuel.

According to Meireles de Barros, the Gasoline Complex start-up project manager, "It took us less than 20 hours to load the 70 -cubic meter HF acid storage tank with hydrofluoric acid for the first time. We transferred the acid catalyst from tanker trucks into the Phillips unit simply by pressurizing the unit with nitrogen, then pumping nitrogen into the tanker trucks, pushing the hydrofluoric acid into the storage tank safely and with minimal atmospheric vapors," de Barros said.

Petrogal optimized its butene isomer distribution by using this Process, improving its isobutane/olefin ratio and dispersion of reactants at the point of reaction.

The Petrogal Gasoline Complex enhances its feedstocks by using the Phillips Petroleum Hydrisom process to upgrade $\mathrm{C}_{4}$ hydrocarbons through selective hydrogenation and isomerization. The unit selectively hydrogenates butadiene from the FCCU and isomerizes butene-1 into butene- 2 . Using hydroisomerization to saturate elevated levels of butadiene in the olefin feedstock before feed reaches the reactor can reduce acid soluble 


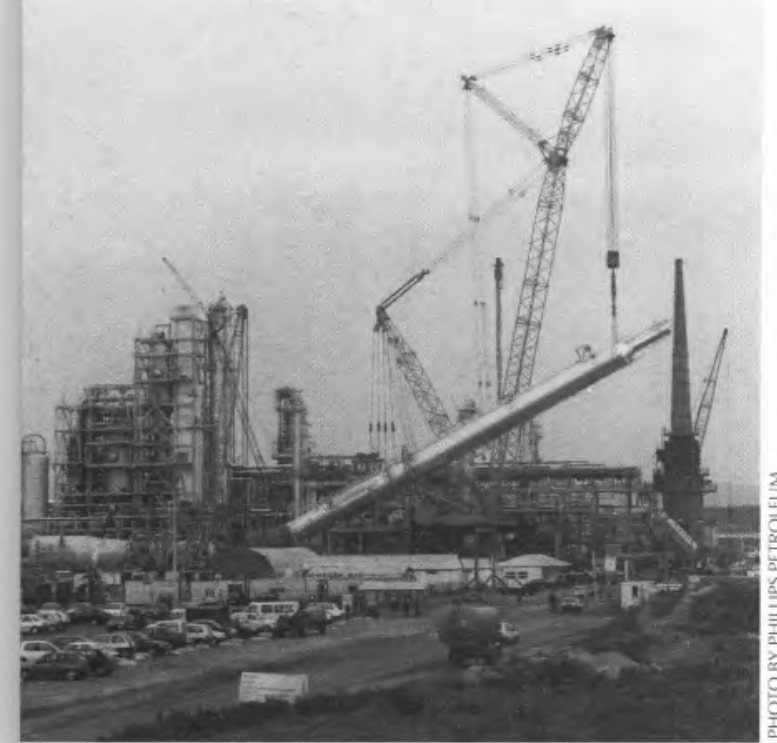

oil (ASO) production in the unit and increase alkylate yield.

"These Hydrisom-treated $\mathrm{C}_{4}$ feedstocks produce higher HF alkylat octane numbers, resulting in additional return on investment for Petrogal," said Pombo Rodrigues.

The Phillips Petroleum-designed HF Alkylation process converts light olefins and isobutane into high-octane alkylate. Because it is cleanburning and can help reduce automotive tailpipe emissions, alkylate is a highly valued component in premium and reformulated gasolines. Also, octane increases are reached at lower reactor temperatures. Thus, the Sines Refinery gains both a safety and cost advantage by keeping reactor temperatures as low as possible.

\section{LABORATORY ANALYSES SUPPORT PRODUCTION QUALITY}

To maintain alkylate quality and ensure optimal production, Petrogal Gasoline Complex planners designed and equipped a complete refinery laboratory within the Complex. And, to make sure that unit operators get the information they need to run the HF Alkylation unit at peak efficiency, lab technicians give alkylate test results directly to control room operators twice a day for any action needed to adjust processing parameters.

\section{SPECIAL EMPHASIS ON HF SAFETY AND CONTROL}

"During the design phase and through construction of the Gasoline Complex, we worked with Phillips to develop the very best safety procedures possible and we began our $\mathrm{HF}$ mitigation activities at an early stage," Pombo Rodrigues said.

The Phillips Petroleum HF Alkylation unit design includes elevated acid coolers and an acid storage tank that is lower than any other HF-containing vessels. This back-up acid storage tank, capable of holding all of the HF and hydrocarbons in the operating system, is part of the Phillips Petroleum-designed rapid acid transfer and vapor mitigation systems.

This design scheme uses a system of remote-control valves and HF's weight to control any potential accidental acid release by completely emptying the main reactor within 10 minutes. This fast response minimizes the amount of acid that can leak from the system, thus containing any HF emissions within the Gasoline Complex.

\section{SPACE-AGE CONTROLS FOR SAFETY}

Petrogal maintains complete control of the HF unit from a sophisticated computerized control room, located in a satellite building one mile from the Gasoline Complex.

From here, operators monitor flow, temperatures, pressures and safety functions. Strategically located sensors on key valves, as well as hydrocarbon and acid detectors on the HF unit, provide operators an early-warning leak-detection system.

Closed-circuit television throughout the Complex compliments the computerized Honeywell TCD 3000 HF unit monitoring system. Four cameras, located at various levels and sites, monitor every major piece of equipment within the Gasoline Complex.

"This remote-site, universal control capability allows the refinery to keep non-essential refinery personnel to a minimum at the HF unit area. Petrogal has a specially-trained maintenance and quality control group, stationed at the unit 24 hours a day," Barros added.

${ }^{*} \mathrm{G}+\mathrm{A}$ Communications

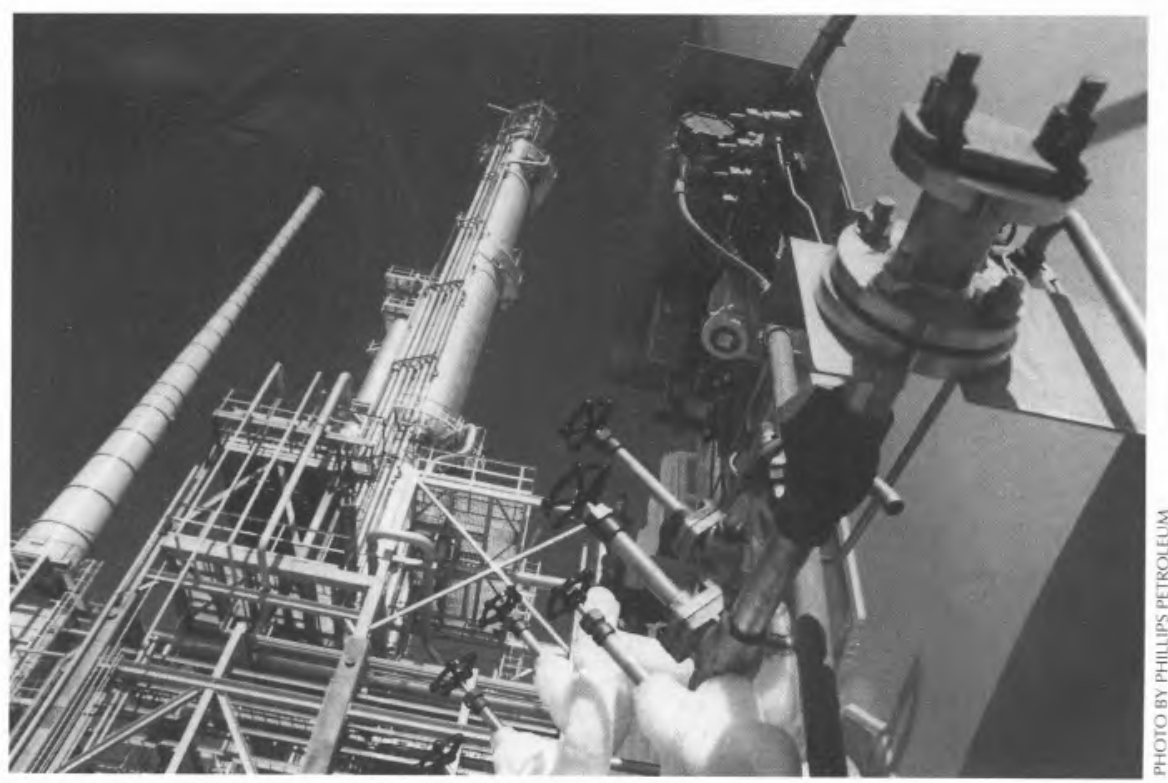




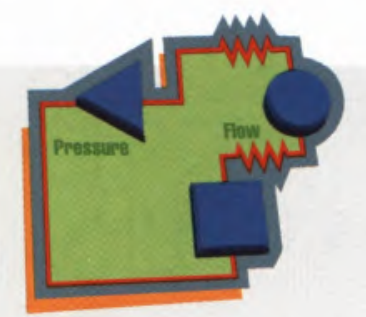

( No more knobs with PPC, programmable pneumatic control

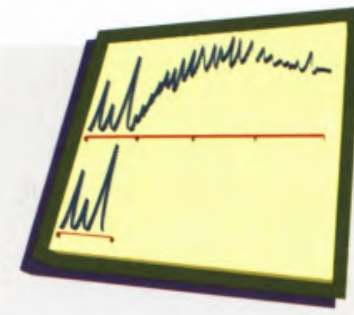

(2) PreVlent ": faster analysis, extended system life

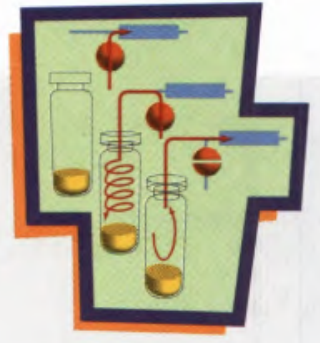

3 Pressure-balanced headspace sampling

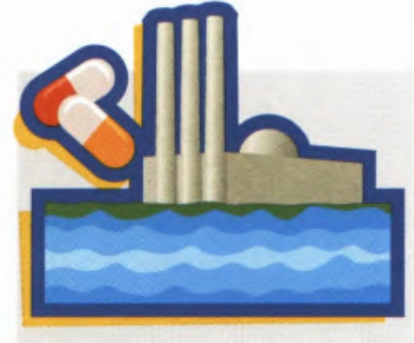

4 Engineered solutions for your special application

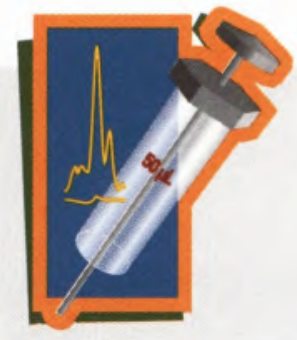

(5) $10 \mathrm{X}$ more sensitivity with large-volume injection

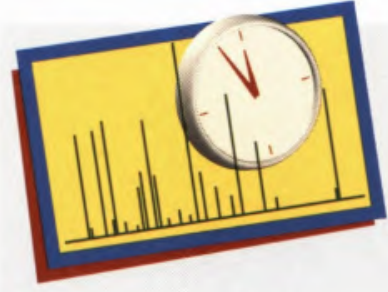

6 Rapid GC/MS pumpdown

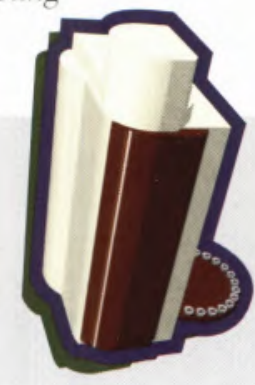

0 Built-in autosampler for greater reliability

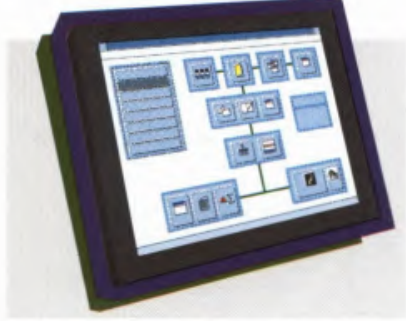

8 Advanced data handling with Turbochrom ${ }^{\mathrm{TM}}$

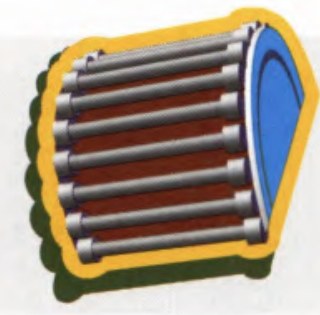

(9) Two-stage thermal desorption improves results

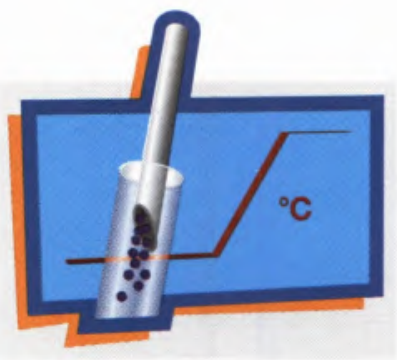

(11) Universal capillary inlet with temperature programming

\section{0 reasons your next GC should be the AutoSystem XL.}

\section{Reason 2: Faster analysis and extended} system life. Improve throughput as much as 10-fold with AutoSystem XL"s unique PreVent mode. ISO 9001 PreVent eliminates high-boiling nontarget compounds before they reach the column. tentifies reducing sample handling and extending column and detector life.

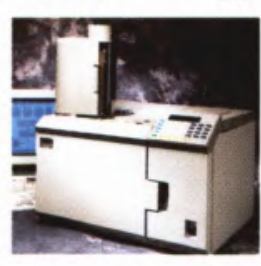

Get the full story from Perkin-Elmer.

For more information about all the reasons your next GC should be the AutoSystem XL, contact Perkin-Elmer through our worldwide service and support network. In the U.S., call 1-800-762-4000. Outside the U.S., contact your Perkin-Elmer representative.

New AutoSystem XL Gas Chromatograph 


\section{GERB $R$ INSTRUM NTS}

(TMT) TAMSON

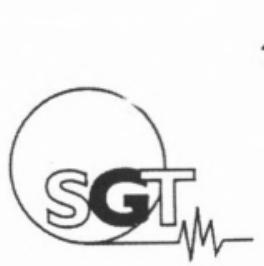

\#75트

\section{METTLER TOLEDO}

FisherScientific

KOJAIR

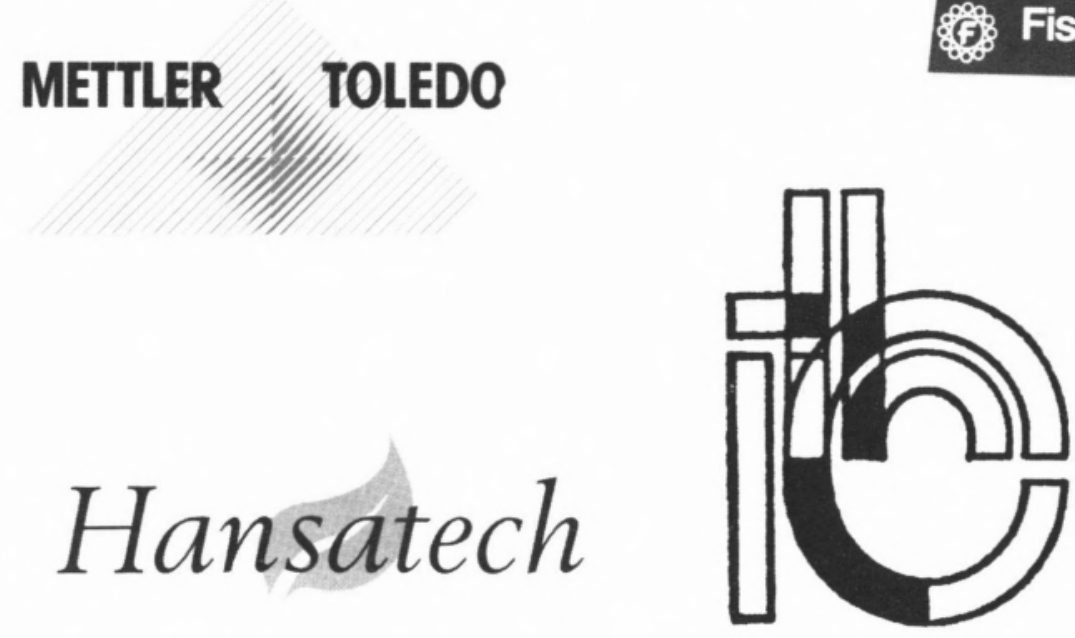

$\triangle$ GOCOA=x

A \& R DESIGNS LTD

UNIEQUIP
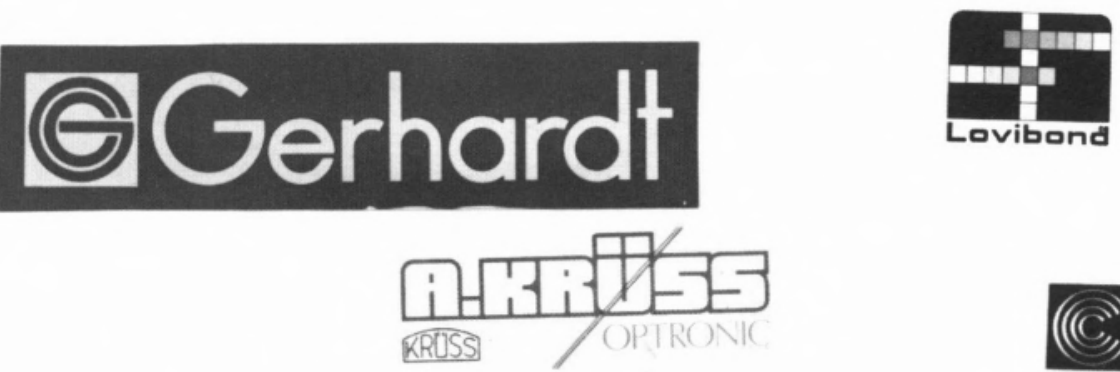

Cathodeon

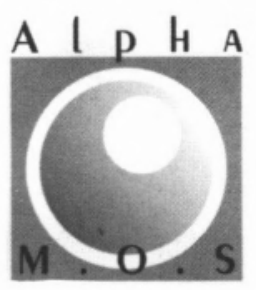

Promochem

\section{CONSORT}

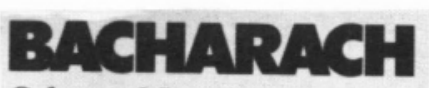

Coleman ${ }^{\circledast}$ Instruments

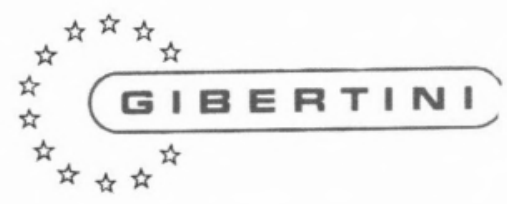

Gaptखăc

instrumentos de laboratório e científicos lda

SEDE: RUA DR. ALVARO DE CASTRO, 77 . TELS. (01)7962172.7963313-7940261(BA). FAX (01)7937035 * 1600 LISBOA AV. DA BOAVISTA, 80, 3\%, SALA 29 TELEF. 6097503 . FAX 6003154 . 4000 PORTO

FILIAIS: RUA MACHADO DOS SANTOS, 61-63. TELEF, 27043 . 9500 PONTA DELGADA-AÇORES

RUA PADRE ESTEVĀO CABRAL, 79, 3.․ SALA 311 . TEL./FAX (039)35022 * 3000 COIMBRA 